\title{
The Effect of Classical Music on Anxiety and Well-Being of University Students
}

\author{
Devrim ERGINSOY OSMANOĞLU ${ }^{1} \&$ Hüseyin YILMAZ ${ }^{2}$ \\ ${ }^{1}$ Department of Educational Sciences, Faculty of Education, Kafkas University, Kars, Turkey \\ ${ }^{2}$ Department of Fine Arts Education, Faculty of Education, Kafkas University, Kars, Turkey \\ Correspondence: Devrim ERGINSOY OSMANOĞLU, Department of Educational Sciences, Faculty of \\ Education, Kafkas University, Kars, Turkey.
}

Received: July 26, 2019

doi:10.5539/ies.v12n11p18
Accepted: August 28, $2019 \quad$ Online Published: October 12, 2019

URL: https://doi.org/10.5539/ies.v12n11p18

\begin{abstract}
Psychological and spiritual effects of music on people have been revealed by various studies and still continue to be investigated. The sound which has existed since the first formation of the universe; and music and music therapy which are as old as the history of mankind have constituted one of the treatment methods widely investigated at hospitals and universities. In the daily lives of people, anxiety, stress, well-being and similar phenomena clearly remain in the foreground. The current study is an experimental study designed to determine the effect of listening to classical music on anxiety and well-being. The sampling of the study is comprised of senior students in an education faculty. A total of 15 students ( 7 females and 8 males) participated in the current study. The data were collected with the State-Trait Anxiety Scale and the Psychological Well-being Scale. In the analysis of the data, Paired Sample t-Test was used.

The findings of the current study have revealed that while listening to classical music for a 60-day period (listening to classical music ever day according to a music listening schedule) did not have any significant effect on the students' State Anxiety scores, it led to a statistically significant effect on their Trait Anxiety and Psychological Well-being scores $(\mathrm{t}=3,451 \mathrm{P}<0,004 ; \mathrm{t}=-3.699, \mathrm{P}<0.002)$. When the pre-test and post-test Psychological Well-being mean scores were compared, no significant difference was found for the sub-dimension of "autonomy", significant differences in favour of post-test scores were found for the sub-dimensions of "positive relations with others", "environmental mastery", "personal growth", "purpose in life", and "self-acceptance".
\end{abstract}

Keywords: music, psychological well-being, state and trait anxiety

\section{Introduction}

From the moment of birth, every person encounters a lot of information from many sources such as culture and social environment. This information is interpreted by a psychic system. These interpretations can lead to positive as well as negative emotions such as anxiety (Manester, Berra, \& Mays, 2001; Drescher, 2007). Anxiety and anxiety-relieving strategies play an important role in the work of many psychoanalytic theorists because researchers agree that anxiety is an unpleasant emotional experience. "Anxiety is a state of extreme concern and fear that a person experiences when he/she encounters a stimulus from the outside or inner world and individual has difficulty in preventing negative physical, emotional and mental reactions (Budak, 2009, p. 418; Özgül, 2003). Freud studied anxiety for many years and argued that this negative feeling was a force resulting from the suppression of impulses and instincts. According to Freud, the function of the concept of anxiety is to stimulate one's defence mechanism and self against any danger (Burger, 2015; Öztürk \& Uluşahin, 2015; Işkın, 2018, p. 5).

There are two types of anxiety; trait anxiety and state anxiety. State anxiety is a state of unease and unhappiness that arises as a result of a temporary situation experienced by the individual but disappears as soon as the threat disappears. The state of which the individual is afraid is evident. In the case of state anxiety, when the person experiences intense fear, physiological reactions such as sweating, fading, flushing and trembling occur in the body. When the threat disappears, anxiety level decreases. This situation is not considered a problem and is necessary for survival in threat situations. The type of anxiety that affects mental health negatively is continuous anxiety. Trait anxiety on the other hand refers to the individual's disposition to experience anxiety. The individual perceives the situations in which he/she is as stressful and tends to interpret events negatively (Kayapınar, 2006; 
Türkçapar, 2012; Aynac1, 2018). Individuals with high level of trait anxiety can generally feel uneasiness and unhappiness (Öner \& Le Compte, 1983).

Long-term anxiety affects negatively the individual's sense of satisfaction about life. Diener (1994) argued that the most important element in the formation of an individual's sense of satisfaction with life is his or her perception of the world. (Deiner, 2000). According to Diener, the presence of positive emotions is frequent, negative emotions are less and life satisfaction is high, indicating good life or happiness (subjective well-being) (Proctor, 2014). According to Diener, the presence of positive affections is frequent, negative affections are less, and a high sense of satisfaction with life is indicative of good life or happiness (subjective well-being) (Proctor, 2014).When positive feelings are frequent and intense and negative feelings are relatively low and when activities in life provide satisfaction, subjective well-being of individuals increases. This suggests that anxiety may have a significant relationship with subjective well-being (Öztürk \& Çetinkaya, 2015). Subjective well-being has two components: emotional and cognitive. According to Myers and Deiner (1995), besides these two components there is a third component called life satisfaction (Cited in Özen, 2010). In the positive affective dimension of subjective well-being, emotions such as joy, excitement, pride, hope, interest, alertness and trust are found while in its negative affective dimension, feelings such as sadness, guilt, hate, anxiety and anger are found. In the third dimension which is called life satisfaction, the individual's sense of satisfaction and evaluations about various living spaces are found. In order to say that an individual's level of subjective well-being is high, his/her life satisfaction should be high and experience positive feelings frequently yet negative feelings occasionally (Eryllmaz, 2010).

The World Health Organization (WHO) has defined positive mental health as a state of well-being in which the individual is aware of his or her abilities, can cope with the stress of daily life, work productively and contribute to society" (Huppert, 2009). The state of well-being has always existed psychologically in human life. According to Huppert (2009), psychological well-being is a combination of having a good life and feeling well and functioning effectively. Sustainable well-being does not require individuals to always feel good; experiencing painful emotions (e.g. frustration, failure, and sadness) is a normal part of life; being able to struggle with these negative and painful emotions is essential for long-term well-being. However, when negative emotions such as anxiety are severe or prolonged, the psychological well-being interferes negatively with an individual's ability to maintain daily life with positive emotions (Cited in Göçet-Tekin, 2014, pp. 9-12).

For this reason, various treatment and therapy methods are used to minimize these negative emotions and increase the feeling of satisfaction with life. Music believed to have a mystical power since ancient Greek has been reported to lead to emotional changes, relieve and reduce stress by many studies (Juslin \& Sloboda, 2010). In the history of Islamic civilization, especially Sufis who have been interested in Sufism have used music and argued that it has a psychological effect. Sufis mentioned that mental and neurological diseases have been treated with music (Çoban, 2005, p. 38). One of the great Islamic scholars and philosophers, Ibn Sina (980-1037) stated that he benefited a lot from the works of Farabi and even learned music from him and applied it to the medical profession and said: "One of the best and most effective ways of treatment is to enhance the patient's mental and spiritual powers, to encourage him to fight the disease better, to make the patient's environment charming and pleasant, to play the best music and bring him/her together with his/her beloved ones." According to Ibn Sina, changes in tone of voice indicate human moods and it is not our hearing power that makes music compositions pleasing to us, but our ability to comprehend various inspirations from that composition (Somakç1, 2003, p. 135). In every period of human life is believed to have a relaxing effect, which is a way of expressing their feelings and people music, in addition to being an art form, thinking about making a positive contribution to the field of human psychology has been used in therapy and treatment (Gencel, 2006, p. 705; Sezer, 2011, p. 1474; Engraved \& Saglamtimur, 2016, p. 78). Music, which is believed to have a relaxing effect in every period of human life and is one of the ways of expressing human emotions, has been used in the field of therapy and treatment, considering that it contributes positively to human psychology as well as being an art form (Gencel, 2006, p. 705; Sezer, 2011, p. 1474; Oyan \& Sağlamtimur, 2016, p. 78).

The World Federation of Music Therapy (WFMT) defines music therapy as follows: "It is the use of music and musical elements professionally to optimize the quality of life of individuals, groups, families or communities and to improve their physical, social, communicative, spiritual, intellectual, emotional health and well-being as a means of intervention in educational and medical fields or in daily life" (WFMT, 2011). According to results reported by Music Therapy Research Centre music results in positive outcomes in patients with psychological and psychiatric problems, behavioural disorders and neurological problems (MÜTEM, 2015).

Music has a power to affect mental states such as anxiety and well-being. Music is an important stimulus for physical and psychological treatments of people. It can be said that with the musical melodies and rhythms created 
within the existing basic harmony, music meets the need for psychological and physical well-being. Sezer (2009) examined the effects of different music genres on people experimentally and found that therapeutic music positively affected individuals' psychological states. Babacan (1998) reported that in the mother's womb, the mother's heartbeats sound like music to the baby, the baby feels peaceful and leaning on his/her mother's chest after birth comforts him/her. In the experiments, it was observed that the babies who listened to recorded sounds of heart beating were sleeping earlier compared to the babies who were sleeping in a silent room listening to the recorded lullaby (Babacan, 1998). According to Yücelen (2006), the main purpose of music treatment is to re-stimulate forgotten emotions and change the current mood of the person and help him/her to adapt to healthy living conditions by producing new emotions. Music provides positive therapeutic effects in autistic, passive, stressful, depressed people and spastic and disabled people both in the form of changing emotions and developing ability of movement through exercise (Cited in Çan \& Altınköprü, 2013, p. 264).

The music we listen to can affect our inner world, our soul and our emotions: It can lead us to feel happy, creative and enthusiastic and to think positively and can treat mental illnesses caused by anxiety and stress. It is a fact that some certain modes of music, music styles (classical, jazz, pop, mysticism, etc.), rhythms (slow-fast) have spiritual/physical curative effects on human beings and some other living things. According to Frank (1985), the main goal of music therapy is to improve quality of life and the ability to express oneself by reducing distress, fear and anxiety. At the same time, it aims to help the patient recover from physical discomfort, to teach how to relax, to contribute to the mastery of coping strategies by providing leisure activity training and to create a therapeutic environment. Contrary to all these positive effects, some studies have found that music creates negative emotions (Güner, 1998; Ögel et al., 2007). Therefore, it is of great importance to determine the correct styles of music for individuals to experience positive feelings. As a result of the review of the related literature, it was found that there is a general agreement on the positive effects of classical music on human psychology in terms of reducing anxiety and stress and promoting well-being; thus, it was decided to use classical music. Classical music is a polyphonic music of European origin, which is generally associated with a high level of culture and separated from eastern and western folk music. Although it has not been as popular as folk music, it has come from past to present as a style that music enthusiasts from all cultures listen to. Psychology has been closely interested in the effects of music on the organism. However, it is seen that classical music has been used more than other music genres as a variable in the relational surveys between music and psychology. Scientists have studied the effects of classical music on a variety of species, from humans to animals, even to plants (Campbell, 2002).

In the current study, it is aimed to investigate how music affects people's anxiety and well-being in their daily lives, what kind of effect music has on the control of anxiety and well-being and whether music is influential on individuals' psychological states and thus to make suggestions within the context of preventive guidance in light of the findings about the effect of music on anxiety and well-being. In the current study, classical music was played in the process of experimental group application without a control group and the effects of music particularly those of classical music on anxiety and well-being were examined. In the current study, the hypotheses given below were tested:

1) There is a significant difference emerging at the end of the application between the experimental group students' posttest trait and state anxiety scores and the pretest trait and state anxiety scores in favour of the posttest.

2) There is a significant difference emerging at the end of the application between the experimental group students' posttest well-being scores and pretest well-being scores in favour of the posttest.

\section{Method}

The current study was designed according to the experimental model and employed the single group pretest-posttest without control group research design.

\subsection{Experimental Group}

The experimental group of the current study is comprised of 15 students ( 7 females and 8 males) attending the Department of Guidance and Psychological Counselling of Kafkas University. While selecting the participants of the current study, a total of 50 students were administered the Psychological Well-being Scale and the Trait-State Anxiety Inventory and then the students with relatively higher levels of anxiety were selected

\subsection{Data Collection Tools}

\subsubsection{State-Trait Anxiety Inventory}

The State-Trait Anxiety Inventory is a four-point Likert-type scale developed by Spielberger et al. (1970) with the response options ranging from "Not at all" to "Completely". The reliability and validity studies of the inventory in 
Turkish were conducted by Öner (1977). There are two types of statement in the State-Trait Anxiety Inventory. Direct statements express negative emotions while reverse coded statements express positive emotions. In the State Anxiety Inventory, the items 1, 2, 5, 8, 10,11, 15, 16, 19 and 20 are reverse coded items. In the Trait Anxiety Inventory, the items 21, 26, 27, 30,33,36 and 39 are reverse coded items. After calculating the total weights of the direct and reverse coded items separately, the total weighted score calculated for the reverse coded items is subtracted from the total weighted score calculated for the direct items. Then, a pre-determined and constant value is added to this score. For the State Anxiety Inventory, this value is 50 while for the Trait Anxiety Inventory it is 35 . The final score obtained represents the individual's anxiety score (Dalaner, 2000; Öner \& Le Compte, 1983). For this study, the internal consistency reliability coefficient of the state trait anxiety scale was calculated as .91 .

\subsubsection{Psychological Well-Being Scale}

The Psychological Well-being Scale was developed by Ryff (1989) to evaluate the individual's psychological well-being. The Psychological Well-being Scale adapted to Turkish by Cenkseven (2004) is an 84-item scale consisted of 6 sub-dimensions under each of which there are 14 items. The lowest score to be taken from the scale is 84 while the highest score is 504 . Increase seen in the total score shows that psychological well-being is improving. The scale was developed to measure the six sub-dimensions of psychological well-being: 1) Self-determination - independence, personal decisiveness, autonomy 2) environmental mastery - the individual's managing his/her own life, 3) personal growth - being open to new experiences, 4) positive relations with others - feeling satisfied with his/her relations, 5) purpose in life - the individual's believing that his/her life is meaningful, 6) self-acceptance - having positive attitudes towards self and his/her past. Each of the 6 factors in the scale has 14 items. For this study, the internal consistency reliability coefficient of the subjective well-being scale was calculated as 97 .

\subsection{Data Analysis}

In the analysis of the collected data, SPSS 20 program package was used. Paired Sample T test was used in the analysis of the data.

\subsection{Experimental Application Process}

In the current study, first the experimental group students were administered the State-Trait Anxiety Inventory and the Psychological Well-being Scale. Then, six works of Mozart were loaded to the mobile phones of the participating students with their consent to be listened to at least once a day for a 60-day period. In order to ensure that the participating students would regularly listen to music, they were asked to fill in the Music Listening Schedule at the end of each day. At the end of this 60-day period, the State-Trait Anxiety Inventory and the Psychological Well-being Scale were re-administered.

\section{Findings}

According to the results of Shapiro-Wilk Test conducted to determine whether the data show a normal distribution, except for the pretest sub-dimension of self-acceptance, in all the other sub-dimensions, the distribution of the data was found to be normal. The results of Paired Sample T-test conducted on the collected data are given in Table 1. 
Table 1. Experimental group students' pretest-posttest state anxiety, trait anxiety and subjective well-being scores

\begin{tabular}{|c|c|c|c|c|c|c|c|}
\hline & $\mathrm{N}$ & Mean & Standard deviation & Std. Error Mean & $\mathrm{t}$ & $\mathrm{df}$ & sig \\
\hline Pretest State Anxiety & 15 & 41.7333 & 5.10555 & 1.318 & \multirow{2}{*}{-1.311} & \multirow[t]{2}{*}{14} & \multirow{2}{*}{.211} \\
\hline Posttest State Anxiety & 15 & 44.4000 & 5.20714 & 1.344 & & & \\
\hline Pretest Trait Anxiety & 15 & 49.8000 & 4.94542 & 1.276 & \multirow{2}{*}{3.451} & \multirow[t]{2}{*}{14} & \multirow{2}{*}{.004} \\
\hline Posttest Trait Anxiety & 15 & 43.8667 & 4.76395 & 1.230 & & & \\
\hline Pretest Positive Relations with Others & 15 & 57.9333 & 13.98196 & 3.610 & \multirow{2}{*}{-2.913} & \multirow[t]{2}{*}{14} & \multirow{2}{*}{.011} \\
\hline Posttest Positive Relations with Others & 15 & 70.6000 & 8.32209 & 2.148 & & & \\
\hline Pretest Autonomy & 15 & 56.4667 & 12.30486 & 3.177 & \multirow{2}{*}{-1.917} & \multirow[t]{2}{*}{14} & \multirow{2}{*}{.076} \\
\hline Posttest Autonomy & 15 & 63.2000 & 6.72097 & 1.735 & & & \\
\hline Pretest Environmental Mastery & 15 & 50.8667 & 14.80283 & 3.822 & \multirow{2}{*}{-4.348} & \multirow[t]{2}{*}{14} & \multirow{2}{*}{.001} \\
\hline Posttest Environmental Mastery & 15 & 67.4000 & 4.77793 & 1.233 & & & \\
\hline Pretest Personal Growth & 15 & 61.4667 & 13.06504 & 3.373 & \multirow{2}{*}{-2.838} & \multirow[t]{2}{*}{14} & \multirow{2}{*}{.013} \\
\hline Posttest Personal Growth & 15 & 71.8000 & 6.41650 & 1.656 & & & \\
\hline Pretest Purpose in Life & 15 & 54.6000 & 10.74909 & 2.775 & \multirow{2}{*}{-3.167} & \multirow[t]{2}{*}{14} & \multirow{2}{*}{.007} \\
\hline Posttest Purpose in Life & 15 & 66.2667 & 7.90539 & 2.041 & & & \\
\hline Pretest Self-acceptance & 15 & 48.4667 & 10.46673 & 2.702 & \multirow{2}{*}{-5.396} & \multirow[t]{2}{*}{14} & \multirow{2}{*}{.000} \\
\hline Posttest Self-acceptance & 15 & 65.1333 & 4.59606 & 1.186 & & & \\
\hline Pretest Subjective Well-being Total & 15 & 329.8000 & 67.95818 & 17.546 & \multirow{2}{*}{-3.699} & \multirow[t]{2}{*}{14} & \multirow{2}{*}{.002} \\
\hline Posttest Subjective Well-being Total & 15 & 404.4000 & 26.76832 & 6.911 & & & \\
\hline Pretest Anxiety Total & 15 & 91.5333 & 8.14043 & 2.10185 & \multirow{2}{*}{1.013} & \multirow[t]{2}{*}{14} & \multirow{2}{*}{.328} \\
\hline Posttest Anxiety Total & 15 & 88.2667 & 8.14570 & 2.10321 & & & \\
\hline
\end{tabular}

As can be seen in Table 1, while there is no significant difference between the pretest and posttest scores taken from the State Anxiety Scale $(p=.211>0.05)$, there is a significant difference between the pretest and posttest scores taken from the Trait Anxiety Scale $(\mathrm{p}=.004<0.01)$. This shows that music reduces the level of trait anxiety. Moreover, significant differences were found between the pretest mean scores and posttest mean scores calculated for the Psychological Well-being Scale's sub-dimensions of "positive relations with others" $(\mathrm{p}>.05)$; "environmental mastery" ( $>.01)$; "personal growth" $(p>.05)$; "purpose in life" $(p>.01)$ and "self-acceptance" $(\mathrm{p}>.001)$ in favour of the posttest mean scores. When the total Psychological Well-being Scale scores are examined, it is seen that there is an increase in the posttest mean scores. Although there is an increase observed in the Psychological Well-being Scale's sub-dimension of "autonomy" in the posttest, this increase is not statistically significant with a "p" value higher than .05 . As a conclusion, a significant reduction was observed in the participating students' anxiety level and a significant increase in their subjective well-being level.

\section{Discussion, Conclusion, and Recommendations}

Music is one of the important elements in increasing the ability to express oneself, reducing anxiety, treating physiological disorders, managing time effectively and learning coping strategies and improving the quality of life. Music, which is believed to be a relaxing force in every period of human life, can trigger many emotions and these emotions can be positive or negative depending on the genre of music (Assal \& Domasio, 2014). In many studies, it has been found that music causes significant changes in the nervous systems of the brain and changes in the waves such as beta, theta, alpha, and delta in the brain (O'Hagan, 2016; Rüütel, 2002).

In recent years, psychology has been a preferred method, considering that music therapy methods have positive effects on the client (Çam \& Altınköprü, 2013). The results of this research showed that regular listening to classical music reduced anxiety levels and increased subjective well-being levels. O'Hagan (2016) and Knight and Rickard (2001) have also examined the effect of music on anxiety and found that therapeutic music activities were effective in reducing anxiety levels.

Another study reporting results similar to those of the current study was conducted by Sezer (2009) on the effects of music therapy on anger, anxiety and psychological symptoms among high school and university students. As a result of the study conducted with 44 high school students, it was found that music therapy had a positive effect on anger control of adolescent students. Uzun's (2018) study found that music therapy applications were effective in adolescents' relaxation, increasing their self-confidence, enhancing their anger control, reducing their anxiety, establishing and maintaining communication and improving their attention and concentration, and cognitive and mental development.

$\mathrm{Wu}$ (2002) conducted 20-hour music therapy in the experimental group to determine the effect of music on anxiety, 
depression, and self-esteem. Both qualitative and quantitative methods were used in the study. The quantitative results of the study showed that participants' anxiety and depression decreased while their self-esteem increased. When the qualitative data were examined, it was found that the people in the experimental group enjoyed life more, their feelings of relaxation and confidence increased and they experienced less negative emotions.

Gagner-Tjellesen et al. (2001) stated that listening to music may stimulate the alpha waves in the brain that cause relaxation, or may not only reduce pain, but also increase endorphin secretion, which leads to other physiological responses, such as drop in blood pressure and pulse (Yıldırım \& Gürkan, 2007; cited in Sezer, 2011). Güner (1998) conducted a study to examine the effects of different music styles such as arabesque, heavy metal and classical western music on the aggression levels of adolescents and found that the adolescents preferring to listen to heavy metal music exhibit significantly more aggressive and anxious behaviours when compared to the other groups. Ögel et al. (2007) reported that adolescents having substance abuse prefer rap-hip hop-techno-dance music more. In particular, there is also evidence that rock and metal music can have a devastating impact on young people.

As can be seen from the scientific research mentioned above, music can have both positive and negative effects on all living species. It can be said that music has some therapeutic effects on various mental illnesses and that some types of musical instruments, modes and genres have been used to treat mental problems such as anxiety, depression, stress, irritability, panic attack, insomnia, attention disorder, hyperactivity, learning disorders. Given that the music listened to can have negative effects, adolescents should be or must be informed about the types of music they prefer to listen to. For this reason, it is important to prepare music lesson content in schools in a more effective and instructive manner. It is believed that introducing different types of music to the individual from the early years of life and carefully selecting the elements of the music, such as lyrics, content and rhythm, will contribute positively to their mental health. But music alone would not have been enough given the fact that it was effective in other variables at the foundations of mental health. Music can only be used as a supporting method alongside different applications.

\section{References}

Akın, A. (2008). Scales of psychological well-being: A study of validity and reliability. Educational Science: Theory \& Practice, 8, 721-750.

Assal, H., \& Domasio, A. (2014). Music, Feelings, and the Human Brain. Psychomusicology: Music, Mind, and Brain, 24(1), 92-102. https://doi.org/10.1037/pmu0000033

Aynacı, B. (2018). Aile Danışmanlı̆̆ Merkezine Başvuran Kişilerin Kaygı Düzeyleri İle Dindarlık Durumlarının İlişkisi. İstanbul Ticaret Üniversitesi Sosyal Bilimler Enstitüsü Aile Danışmanlığı Ve Eğitimi Anabilim Dalı Aile Danışmanlığı Ve Eğitimi Yüksek Lisans Programı. Yüksek Lisans Tezi.

Babacan, Ş. İ. (1998). Türkiye'de Ruh Hastalıklarının Tedavisinde Müziğin Rolünün Müzik Eğitimi Açısından Incelenmesi ve Yorumlaması. Yayımlanmamış Yüksek Lisans Tezi, Gazi Üniversitesi, Fen Bilimleri Enstitüsü, Ankara.

Budak, S. (2009). Psikoloji Sözlüğü (4. Basım). Ankara. Bilim ve Sanat Yayınları.

Burger, J. M.(2006). Personality. İstanbul: Kaknüs Psikoloji.

Campbell, D. (2002). Mozart etkisi, Kitap matbaascllı, İstanbul.

Çam, O., \& Altınköprü, H. (2013). Üniversite Öğrencilerinde Müziğin Ruhsal Duruma ve Stresle Başa Çıkma Tarzları Üzerine Etkisi/Motif Akademi Halkbilimi Dergisi/2013-2 (Temmuz-Aralık) (Kıbrıs Özel Saylsı-II) (pp. 262-272).

Çoban, A. (2005). Müzik Terapi, Ruh Sağlı̆̆ İçin Müzikle Tedavi. Timaş Yayınları, İstanbul.

Dalaner, H. (2000). Inseminasyon Uygulanacak Kadınlarda İnseminasyon Öncesi ve Sonrası Durumluk-Sürekli Kaygı Düzeylerinin İncelenmesi. Yayınlanmamış Yüksek Lisans Tezi, Ege Üniversitesi.

Diener, E. (2000). Subjective Well-Being The Science of Happiness and a Proposal for a National Index. American Psychologist, 55(1), 34-43. https://doi.org/10.1037/0003-066X.55.1.34

Diener, E., Suh, E., Lucas, R. E., \& Smith, H. L. (1999). Subjective Well-being: Three decades of progress. Psychological Bulletin, 125(2), 276-302. https://doi.org/10.1037/0033-2909.125.2.276

Drescher, K. A. (2007). The Relationship Between The Global Assesment of Functioning and Degrees of Social Interest (Unpublish doctor thesis). Illinois, Chicago: Adler school of professional psychology.

Eryılmaz, A. (2010). Ergenlerde Öznel İyi Oluşu Artırma Stratejilerini Kullanma İle Akademik Motivasyon Arasındaki İlişki. Klinik Psikiyatri, 13, 77-84. 
Frank, J. M. (1985). The effect of music therapy and guided visual imagery on chemotherapy induced nausea and vomiting. Oncol Nurs Forum (p. 12).

Gagner-Tjellesen, D., Yurkovich, E. E., \& Gragert, M. (2001). Use of music therapy and other ITNIs in acute care. Journal of psychosocial nursing and mental health services, 39(10), 26-37.

Gençel, Ö. (2006). Müzikle tedavi. Kastamonu Eğitim Dergisi, 14(2), 697-706.

Göçet-Tekin. E. (2014). Üniversite Öğrencilerinin Psikolojik İyi Olma Duygusal Zeka Ve Sosyal İyi Olma Düzeyleri Arasındaki Illişkilerin İncelenmesi. Doktora Tezi, Sakarya Üniversitesi Eğitim Bilimleri Enstitüsü Eğitimde Psikolojik Hizmetler Anabilim Dalı Psikolojik Danışmanlık Ve Rehberlik Bilim Dalı.

Güner, N. (1998). Ergenlerin Dinledikleri Müzik Türü İle Saldırganlık Düzeyleri Arasındaki İlişkinin İncelenmesi, VII. Ulusal Eğitim Bilimleri Kongresi, Konya, 1, 291-299.

Huppert, F. A. (2009). A New Approach to Reducing Disorder and Improving Well-being. In E. Diener (Ed), Perspectives on Psychological Science, 4, 108-111. https://doi.org/10.1111/j.1745-6924.2009.01100.x

Işgın, S. (2018). Mesleki Müzik Eğitimi Veren Kurumlarda Performans Kaygısı ve Öz-Yeterlik Algısının Çalgl Başarısına Etkisi, Marmara Üniversitesi Eğitim Bilimleri Enstitüsü Güzel Sanatlar Eğitimi Anabilim Dalı Müzik Öğretmenliği Bilim Dall. Yüksek Lisans Tezi, İstanbul.

Juslin, P., \& Sloboda, J. (2010). Introduction: Aims, organization and terminology. In P. Juslin, \& J. Sloboda (Eds.), Handbook of Music and Emotion: Theory, Research, Applications (pp. 2-14). Oxford and New York: Oxford University Press.

Kayapınar, E. (2006). Ortaöğretim kurumları öğrenci seçme ve yerleştirme slnavı (OKS)'na hazırlanan ilköğretim 8. slnıf öğrencilerinin kaygı düzeylerinin incelenmesi (Afyonkarahisar İli Örneği). (Master's thesis, Afyon Kocatepe Üniversitesi, Sosyal Bilimler Enstitüsü).

Knight, W. E. J., \& Rickard, N. S. (2001). Relaxing Music Prevents Stressinduced Increases in Subjective Anxiety, Systolic Blood Pressure, and Heart Rate in Healthy Males and Females. Journal of Music Therapy, 38(4), 254-272. https://doi.org/10.1093/jmt/38.4.254

Köknel, Ö. (1989). Genel ve Klinik Psikiyatri. Nobel Tıp Kitabevi, İstanbul.

Manester, G., Berra, S., \& Mays, M. (2001). Manaster perryman early recollections scoring manual: Findings and summary. Journal Of İdividual Psychology, 57(4), 413-419.

Myers, D. G., \& Diener, E. (1995). Who is happy? Psychological Science, 6(1), 10-19. https://doi.org/10.1111/j.1467-9280.1995.tb00298.x

O'Hagan, E. (2016). The Relationship Between Listening to Music and Feelings of Anxiety and Happiness in Young Adults.

Oyan, S., \& Sağlamtimur, B. (2016). Müziğin İnsanlar ve Çeşitli Canlılar Üzerine Etkilerinin Değerlendirilmesi. İnönü Üniversitesi Kültür ve Sanat Dergisi, 2(1), 77-82. https://doi.org/10.22252/ijca.259360

Ögel, K., Ermağan E., Eke, C. Y., \& Taner, S. (2007). Madde Deneyen ve Denemeyen Ergenlerde Sosyal Aktivitelere Katılım: İstanbul Örneklemi. Journal of Dependence, 8(1), 18-23.

Öner, N. (1994). Türkiye'de Kullanılan Psikolojik Testler. Boğaziçi Yayınları, İstanbul.

Öner, N., \& Le Compte, A. (1983). Durumluluk-Sürekli Kaygı El Kitabı. Boğaziçi Üniversitesi Yayınları No: 333, İstanbul.

Özen, Y. (2010). Kişisel sorumluluk bağlamında öznel ve psikolojik iyi oluş (sosyal psikolojik bir değerlendirme). Dicle Üniversitesi Sosyal Bilimler Enstitüsü Elektronik Dergisi, 4, 46-58.

Özgül, F. (2003). Beden Eğitimi ve Spor Yüksek Okulu Öğrencilerinde Durumluk ve Sürekli Kaygı Düzeyleri. Yüksek Lisans Tezi, Cumhuriyet Üniversitesi Sağlık Bilimleri Enstitüsü, Sivas.

Öztürk, A., \& Çetinkaya-Siviş, R. (2015). Eğitim fakültesi öğrencilerinin öznel iyi oluş düzeyleri ile tinsellik, iyimserlik, kaygı ve olumsuz duygu düzeyleri arasındaki ilişki Marmara Üniversitesi Atatürk Eğitim Fakültesi Eğitim Bilimleri Dergisi. Journal of Educational Sciences, 1(42), 335-356. https://doi.org/10.15285/ebd.98899

Öztürk, O., \& Uluşahin, A. (2015). Ruh sağllğı ve bozuklukları (14. Basım). Ankara: Nobel Tıp Kitapevi.

Proctor, C. L. (2014). Subjective Well-Being. Publisher: Springer. https://doi.org/10.1007/978-94-007-0753-5_2905 
Ruutel, E. (2002). The Psychophysiological Effects of Music and VibroacousticStimulation. Nordic Journal of Music Therapy, 11(1), 16-26. https://doi.org/10.1080/08098130209478039

Ryff, C. D. (1989). Happiness is everything, or is it? Explorations on the meaning of psychological well-being. Journal of Personality and Social Psychology, 57(6), 1069-1081. https://doi.org/10.1037/0022-3514.57.6.1069

Sezer, F. (2009). Müzikle Terapinin Sınav Kaygısı, Öfke ve Psikolojik Belirtiler Üzerindeki Etkisi. Yayımlanmamış Doktora Tezi, Atatürk Üniversitesi, Sosyal Bilimler Enstitüsü, Erzurum.

Sezer, F. (2011). Öfke ve psikolojik belirtiler üzerine müziğin etkisi. Uluslararası insan bilimleri dergisi, 8(1), 1472-1493.

Somakc1, P. (2003). Türklerde Müzikle Tedavi. Erciyes Üniversitesi Sosyal Bilimler Enstitüsü Dergisi, 15(2), 131-140.

Spielberger, C. D., Gorsuch, R. L., \& Lushene, R. E. (1970). Manual for Stait-Trait Anxiety Inventory. California, Consulting Psychologist Press.

Telef, B. B. (2013). Psikolojik iyi oluş ölçeği: Türkçeye uyarlama, geçerlik ve güvenirlik çalışması. Hacettepe Üniversitesi Eğitim Fakültesi Dergisi [Hacettepe University Journal of Education], 28(3), 374-384.

Türkçapar, Ü. (2012). Güreşçilerin farklı değişkenler açısından sürekli kaygı düzeylerinin incelenmesi. Gefad/Gujgef, 32(1), 129-140.

Uçan, A. (1994). İnsan ve Müzik-İnsan ve Sanat Eğitimi. Ankara: Müzik Ansiklopedisi Yayınları.

Uzun, G. (2018). Lise öğrencilerinin ruhsal gelişimi ve ergenliğe bağlı negatif etkilerin.

Wu, S. M. (2002). Effects Of Music Therapy On Anxiety. Depression and Self Esteem of Undergraduates. Psychologia, 45(2), 104-114. https://doi.org/10.2117/psysoc.2002.104

Yildirim, S., \& Gürkan, A. (2007). Müzigin, kemoterapi yan etkilerine ve kaygi düzeyine etkisi. Anadolu Psikiyatri Dergisi, 8(1), 37.

Yücelen, E. (2006). Eski Türklerde Müzikle Tedavi.

\section{Copyrights}

Copyright for this article is retained by the author(s), with first publication rights granted to the journal.

This is an open-access article distributed under the terms and conditions of the Creative Commons Attribution license (http://creativecommons.org/licenses/by/4.0/). 